\title{
Increased Recombination Adjacent to the Huntington Disease-Linked D4S10 Marker
}

\author{
Bernice A. Allitto, * Marcy E. Macdonald, * Maja Bucan, $\dagger$ Julia Richards, $†$ Donna Romano, * \\ W. Lance Whaley, ${ }^{*}$ Barbara Falcone, ${ }^{*}$ James IanazzI, ${ }^{*}$ Nancy S. WeXler,,.$l l$

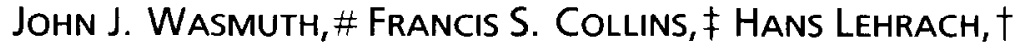 \\ Jonathan L. HaINES, ${ }^{\star}$ AND JAMES F. GUSELla*
}

*Neurogenetics Laboratory, Massachusetts General Hospital and Department of Genetics, Harvard Medical School, Boston, Massachusetts 02114; †Imperial Cancer Research Fund, Lincoln's Inn Fields, London, WC2A 3PX, United Kingdom; $\ddagger$ Howard Hughes Medical Institute, University of Michigan, Ann Arbor, Michigan 48109; §Department of Neurology, Columbia University, New York, New York 10032; "Hereditary Disease Foundation, 606 Wilshire Boulevard, Suite 504, Santa Monica, California 90401; and \#Department of Biological Chemistry, University of California, Irvine, California 92717

Received April 30, 1990; revised August 17, 1990

Huntington disease (HD) is caused by a genetic defect distal to the anonymous DNA marker $D 4 S 10$ in the terminal cytogenetic subband of the short arm of chromosome 4 (4p16.3). The effort to identify new markers linked to $H D$ has concentrated on the use of somatic cell hybrid panels that split 4p16.3 into proximal and distal portions. Here we report two new polymorphic markers in the proximal portion of 4 p16.3, distal to D4S10. Both loci, D4S126 and $D 4 \$ 127$, are defined by cosmids isolated from a library enriched for sequences in the 4pter-4p15.1 region. Physical mapping by pulsed-field gel electrophoresis places D4S126 $200 \mathrm{~kb}$ telomeric to D4S10, while D4S127 is located near the more distal marker $D 4 \$ 95$. Typing of a reference pedigree for $D 4 S 126$ and $D 4 S 127$ and for the recently described VNTR marker D4S125 has firmly placed these loci on the existing linkage map of 4 p16.3. This genetic analysis has revealed that the region immediately distal to D4S10 shows a dramatically higher rate of recombination than would be expected based on its physical size. D4S10-D4S126-D4S125 span $3.5 \mathrm{cM}$, but only 300-400 $k b$ of DNA. Consequently, this small region accounts for most of the reported genetic distance between $D 4 S 10$ and $H D$. By contrast, it was not possible to connect D4S127 to D4S125 by physical mapping, although they are only 0.3 cM apart. A more detailed analysis of recombination sites within the immediate vicinity of $D 4 S 1 O$ could potentially reveal the molecular basis for this phenomenon; however, it is clear that the rate of recombination is not continuously increased with progress toward the telomere of 4p. 1991 Academic Press, Inc.

\section{INTRODUCTION}

Huntington disease (HD) is a late-onset neurodegenerative disorder involving progressive choreic movements, cognitive decline, and dementia as a re- sult of specific neuronal cell death (Martin and Gusella, 1986). The dominant genetic defect causing $H D$ has been linked to the DNA marker $D 4 S 10$ at an estimated distance of 3-4 cM (Gusella et al., 1983; Conneally et al., 1989). Mapping of $D 4 S 10$ by dosage studies in Wolf-Hirschhorn syndrome (Gusella et al, 1985), by in situ hybridization (Zabel et al., 1986; Magenis et al., 1986; Wang et al., 1986; Landegent et al., 1986), and by somatic cell hybrid analysis (MacDonald et al., 1987; Smith et al., 1988) has placed the marker in 4p16, most likely in the proximal portion of 4 p16.3, the terminal cytogenetic subhand of the chromosome. Multipoint linkage mapping using a proximal marker has established that the $H D$ gene is located distal to $D 4 S 10$ within $4 \mathrm{p} 16.3$, which constitutes only $3 \%$ of the cytogenetic length of chromosome 4 or approximately $0.2 \%$ of the genome (Gilliam et al., 1987a). Somatic cell hybrid panels that allow DNA probes to be mapped to either the proximal or the distal portions of $4 \mathrm{p} 16.3$ have been conslructed (MacDonald el al., 1987; Smith et al., 1988). These have been used to generate several new markers, including D4S43 (Gilliam et al., 1987b), D4S81 (Richards et al., 1988), D4S95 (Wasmuth et r.. 1988), and D4S125 (Nakamura et al, 1988; MacDonald et al, 1989a) in proximal $4 \mathrm{p} 16.3$ and $D 4 S 90$ (Youngman et al., 1988, 1989), D4S98/S114/S113 (Smith et al., 1988; Whaley et al., 1988), D4S111 (Pohl et al., 1988; MacDonald et al., 1989a), and D4S115/ S96 (Smith et al., 1988; Pohl et al., 1988; MacDonald et al., 1989a) in the distal region. Recent evidence suggests that the $H D$ gene is in the terminal half of 4 p16.3, although the recombination events detected do not permit an unambiguous localization (MacDonald et al., 1989b; Robbins et al., 1989). 
The telomeric location of the $H D$ defect has raised the possibility that it is in a region of relatively increased recombination. It has been suggested, on the basis of both chiasma counts and linkage information, that the frequency of recombination increases as the telomere is approached (Laurie and Hulten, 1985; Tanzi et al., 1988). Initial data derived from a $200-\mathrm{kb}$ chromosome jump toward the telomere from $\mathrm{D} 4 \mathrm{~S} 10$ suggested relatively increased recombination in 4p16.3 (Richards et al., 1988). We have isolated two new DNA markers, D4S126 and D4S127, that map in the proximal portion of $4 \mathrm{p} 16.3$ by somatic cell hybrid analysis. Physical mapping of these markers relative to several previously positioned loci and the assessment of their linkage relationships have revealed much higher than average recombination immediately distal to $14 \$ 10$, accounting for much of the genetic separation between this marker and $H D$. However, this increased rate of recombination was not maintained with further progress toward the telomere, suggesting that specific sequence or structural characteristics in the vicinity of $D 4 S 10$ may promote recombination.

\section{MATERIALS AND METHODS}

\section{Cell Lines}

HHW693 is a human-hamster hybrid cell line containing a human translocation chromosome composed of $4 p t e r-4 p 15.1$ and $5 p 15.1-5 \mathrm{cen}$ from which $5 \mathrm{q}$ has been deleted (Wasmuth et al., 1986). The cosmid library used in this study was prepared by inserting genomic DNA partially digested with Sau3A into the BamHI site of pCOS2 (Poustka et al., 1984). The hybrid cell lines used in the regional mapping panel for $4 \mathrm{p}$ have been described previously (MacDonald et al., 1987; Smith et al., 1988). Human lymphoblastoid cell lines from the Venezuela reference pedigree (Tanzi et al., 1988) were established from blood samples by EBV transformation (Anderson and Gusella, 1984). DNA was prepared from all cell lines as previously described (Gusella et al., 1979).

\section{Cosmid Librarv Screening and Regional Mapping}

Individual cosmids from the library were picked into a gridded array on nitrocellulose filters. After incubation overnight at $37^{\circ} \mathrm{C}$, replica filters were prepared from the master filter, reincubated, and subsequently processed for hybridization (Gusella et al., 1980). Cosmids containing human inserts were then identified by hybridization of duplicate filters to total human genomic DNA or total hamster genomic DNA labeled with ${ }^{32} \mathrm{P}$ by the random hexamer priming technique (Feinberg and Vogelstein, 1983). The filters were washed to a final stringency of $0.1 \times \mathrm{SSC}$ at $65^{\circ} \mathrm{C}$
(Gusella et al., 1980), and cosmids showing stronger hybridization signal with the human probe than with the hamster probe were picked for further characterization. Individual cosmid DNAs were miniprepped by alkaline lysis (Maniatis et al., 1982), labeled with ${ }^{32} \mathrm{P}$ (Feinberg and Vogelstein, 1983), and hybridized directly to regional mapping panels using unlabeled human genomic DNA to suppress repeat sequence hybridization (Sealey et al., 1985).

\section{Linkage Analysis}

Typing of restriction fragment length polymorphisms was carried out by Southern blot analysis as previously described (Gusella et al., 1983). Linkage data were analyzed using the MAPMAKER program to define marker order and to estimate recombination frequencies (Lander et al., 1987).

\section{RESULTS}

\section{Isolation of Probes from 4p 16.3}

Thirty-five cosmids containing human DNA were isolated from a library constructed with DNA from the human-hamster hybrid HHW693 (Wasmuth et al., 1986). This line retains 4 pter-4p15.1 and $5 p 15.1-5$ cen as its only human material. Individual cosmids were labeled with ${ }^{32} \mathrm{P}$, preannealed to human genomic DNA to minimize the contribution of repeat sequences (Sealey et al., 1985), and then used directly as probes against DNA blots of a somatic cell hybrid panel designed to localize them regionally within the terminal half of 4p (MacDonald et al., 1987; Smith et al., 1988). The results are summarized in Fig. 1. As expected, approximately one-half of the clones derived from chromosome 4 (18 of 35) but most mapped centromeric to $4 \mathrm{p} 16.3$. However, two cosmids, BJ14 and BJ56, were assigned to the proximal portion of 4p16.3, the same physical region as D4S10 (Fig. 1). This regional assignment was later confirmed with single-copy probes derived from the cosmids (see example in Fig. 2) which have been assigned the locus names $D 4 S 126$ and $D 4 S 127$, respectively.

\section{Physical Localization of D4S126 and D4S127}

A long-range physical map of $4 \mathrm{p} 16.3$ is emerging from pulsed-field gel electrophoresis studies (Bucan et al., 1990). The map spans over $5000 \mathrm{~kb}$ in the region between $D 4 S 10$ and the telomere of $4 \mathrm{p}$, with two gaps of unknown size, one between D4S125 and D4S95 and one between $D 4 S 113$ and D4S115 (Fig. 3A). A third gap in the map exists proximal to D4S10, which shares no common pulsed-field gel fragments with the D4S62 locus probably located in 4p16.2. 


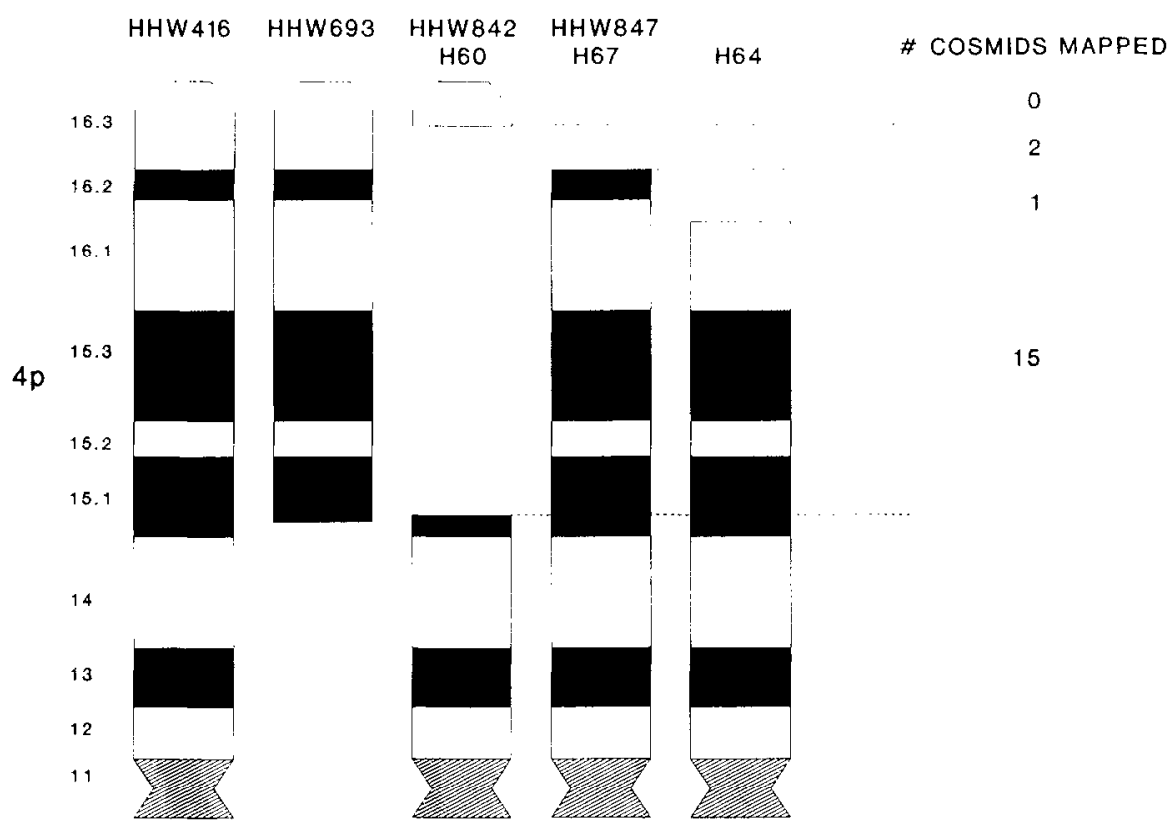

FIG. 1. Regional distribution of chromosome $4 \mathrm{p}$ probes. Eighteen cosmids containing human inserts from the HHW693 library were mapped using a regional somatic cell hybrid panel $(18,32)$. The approximate locations of critical hybrid breakpoints distinguishing regions of 4 p16 are shown under the names of the corresponding cell hybrids. In two cases, comparable human $\times$ mouse and human $\times$ hamster hybrids, containing identical translocation or deletion chromosomes, were available. The numbers of cosmids mapping to each of the four readily distinguishable physical regions are shown.

$D 4 S 126$ and $D 4 S 127$ have been placed on the 4p16.3 physical map by using single-copy subclones (see below) as probes. D4S126 maps between D4S10 and the recently described VNTR marker D4S125, as shown in Fig. 3A. In the cell line GM1416B, BJ14 (D4S126) and YNZ32 (D4S125) detect common NotI and $M l u \mathrm{I}$ fragments, whereas $N r u \mathrm{I}$ digestion yields a common fragment shared by these probes and G8 (D4S10) (Fig. 4). Double digests with these enzymes and mapping with other sources of genomic DNA have produced the map shown in Fig. 3A. D4S126 is located $\sim 200 \mathrm{~kb}$ distal to $D 4 S 10$ and within $60 \mathrm{~kb}$ of $D 4 S 81$, a locus defined previously on the basis of a chromosome jump from D4S10 (Richards et al., 1988). D4S125 maps an additional 100-200 kb telomeric to $D 4 S 126$.

D4S127 maps in a more distal cluster of markers that includes D4S95 and D4S43. Of these three, $D 4 S 127$ is proximal, separated from $D 4 S 95$ by a single $\mathrm{NruI}$ site. It has not yet been possible to connect $D 4 S 125$ and $D 4 S 127$ by pulsed-field mapping but, in addition to a gap of unknown size, they are separated by a minimum of $700 \mathrm{~kb}$ of DNA

\section{Identification of Restriction Fragment Length Polymorphisms}

Single-copy fragments were isolated from BJ14 and BJ56 cosmids by random subcloning using double di- gests with either HindIII or PstI and Sau3AI designed to produce numerous small subclones of $<1.5 \mathrm{~kb}$. Five to ten subclones from each cosmid were screened for RFLPs by hybridization to Southern blots of genomic DNA from five unrelated individuals, each DNA digested with 35-40 restriction enzymes (Gilliam et al., $1987 \mathrm{c}$ ). In some cases, larger restriction fragments excised directly from the cosmid were also used for RFLP screening.

The RFLPs identified are presented in Fig. 5 and Table 1. Two useful RFLPs were found with probes from the BJ14 cosmid. The subclone p309 detected a very informative two-allele system with $S a c I$, while a two-allele $S s p$ I RFLP was visualized using a $2.5-\mathrm{kb}$ $B g l$ I fragment taken directly from the cosmid. Three subclones from BJ56 detected RFLP. p358 reveals a three-allele RFLP with the restriction enzyme PvuII. p359 detects a two-allele PvuII RFLP that is in linkage disequilibrium with the PvuII RFLP of $p 358$ and a second two-allele RFLP with ScaI. A third subclone, p363, detccts a two-allele RFLP with StuI. Except for the PvuII RFLPs detected with p358 and p359, none of the other polymorphisms are in strong disequilibrium with each other, thereby increasing the informativeness of these loci as genetic markers.

Genetic Linkage Relationships of the 4p16.3 Markers

'T'he Venezuela reference pedigree, derived from the large HD kindred responsible for the discovery of link- 


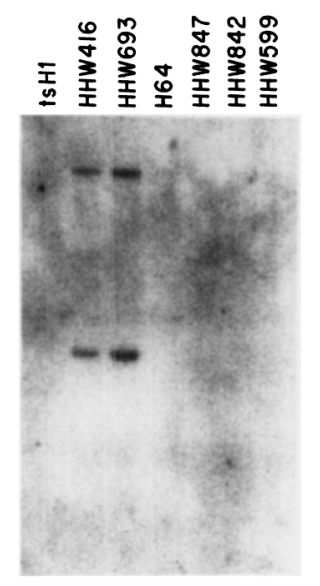

FIG. 2. BJ14 maps to 4p16.3. Each lane contains $5 \mu \mathrm{g}$ of HindIII-digested DNA from hamster or hybrid cell lines fractionated by agarose gel electrophoresis, transferred to nylon filters, and hybridized to probe $\mathrm{p} 309$. $\mathrm{tsH} 1$ is the parent hamster cell line, HHW 416 retains an intact human chromosome 4 as its only human material, and HHW599 contains chromosome 5 as its only human material. The other hybrids contain the chromosome $4 \mathrm{p}$ regions shown in Fig. 1. Since the p309 probe was isolated by random subcloning using Sau3A+HindIII, the detection of two HindIII fragments indicates the presence of two small noncontiguous fragments of the cosmid in this subclone.

age between the disorder and $D 4 S 10$, has previously been used to construct a linkage map of 4 p16.3 (MacDonald et al., 1989b). This map extended from $D 4 S 10$ in proximal $4 \mathrm{p} 16.3$ to $\mathrm{D} 4 \mathrm{~S} 90$ within $250 \mathrm{~kb}$ of the $4 \mathrm{p}$ telomere, and spanned $5.6 \mathrm{cM}$. We have typed the reference pedigree with the RFLPs for $D 4 S 125$, D4S126, and D4S127 to confirm the physical map order and to determine the genetic distance between these loci. Two-point analysis demonstrated these loci to be highly informative in the data set, giving lod scores for linkage to $D 4 S 10$ of 92.78 at $\hat{\theta}=0.04,70.2$ at $\hat{\theta}=0.02$, and 67.3 at $\hat{\theta}=0.03$, respectively. When the loci were tested by multipoint analysis, they fit cleanly into the linkage map without disrupting the previously established marker order. The updated genetic map is given in Fig. 3B. In agreement with the physical map, D4S125 fell between D4S10 and $D 4 S 43 / S 95$, with odds of $10^{7}: 1$ over the next most likely order (D4S10-D4S43/S95-D4S125). Similarly, D4S126 mapped between D4S10 and D4S125, with odds of $10^{7}: 1$ over the next best location, proximal to D4S10. D4S126 showed no crossovers with D4S81, which maps physically to the same region, but is much less informative in this data set. Finally, placement of D4S127 between D4S125 and D4S43/S95 was $10^{2.3}$ times more likely than that between $D 4 S 10$ and D4S125, the second-best location.

Surprisingly, the recombination frequencies for the intervals $D 4 S 10$ to $D 4 S 126$ and D4S126 to D4S125 were 2.4 and $1.1 \%$, respectively, despite the relatively small physical size of this region, which encompasses only 300 to $400 \mathrm{~kb}$ of DNA. By contrast, the physical region of $600-700 \mathrm{~kb}$ separating $D 4 S 95$ from $D 4 S 43$ contained no recombination events in this data set, although both loci are highly informative (pairwise $\operatorname{lod} z=62, \hat{\theta}=0.0$ ). It should be noted that only one or two recombinants would have been expected for this interval (assuming $1 \mathrm{cM}=10^{6} \mathrm{bp}$ ) so that the absence of any recombinants does not constitute significant evidence for a "cold spot" in this region. The physical distance between $04 \mathrm{~S} 10$ and the telomere of $4 \mathrm{p}$ cannot be estimated with certainty because of the two remaining gaps in the long-range restriction map, but must contain a minimum of $4.4 \times 10^{6} \mathrm{bp}$ of DNA. Overall, the map distance from $D 4 S 10$ to $D 4 S 90$ in creased to $6.1 \mathrm{cM}$ with the addition of the three new loci, but more than half of this genetic distance is compressed into 300 to $400 \mathrm{~kb}$ of the physical map. The remaining $4 \times 10^{6}$ or more base pairs between D4S 125 and the telomere constitutes only $2.6 \mathrm{cM}$ of genetic distance, more in line with the $1 \mathrm{cM}=10^{6} \mathrm{bp}$ average expected based on the entire genome. The statistical significance of the apparent increase in recombination near $D 4 S 10$ was tested by using a likelihood ratio test (which approximates $\mathrm{a} \chi^{2}$ ) and the difference in the ratio of genetic to physical distance was found to be highly significant $(P<0.001)$.

\section{DISCUSSION}

The use of DNA markers for human linkage analysis has demonstrated that considerable variation exists throughout the human genome in rates of recombination. Many chromosomal linkage mapping studies have documented dramatically different rates of crossing-over for particular regions in male versus female meioses. Similarly, where physical maps have been available, differences have been observed in the relationship between rate of recombination and physical distance along the chromosomal DNA. For example, on chromosome $21 \mathrm{q}$, fully $10 \%$ of the crossovers occur in the terminal $10 \%$ of the chromosome arm (Tanzi et al., 1988). This relative increase in recombination in the distal region agrees with predictions from the distribution of chiasmata, which also occur most frequently toward the telomere on other chromosomes (Laurie and Hulten, 1985).

'The mapping of the $H D$-linked marker, $D 4 S 10$, near the telomere of $4 p$ has created the impetus for constructing detailed genetic and physical maps of the terminal segment of $4 \mathrm{p}$. Comparison of these maps reveals that there is no continuous increase in the rate of recombination as the telomere is approached. Rather, a striking increase in recombination occurs over a relatively small region of 300 to 400 $\mathrm{kb}$ near $D 4 S 10$, but in the 4 to $5 \times 10^{6}$ bp of DNA 

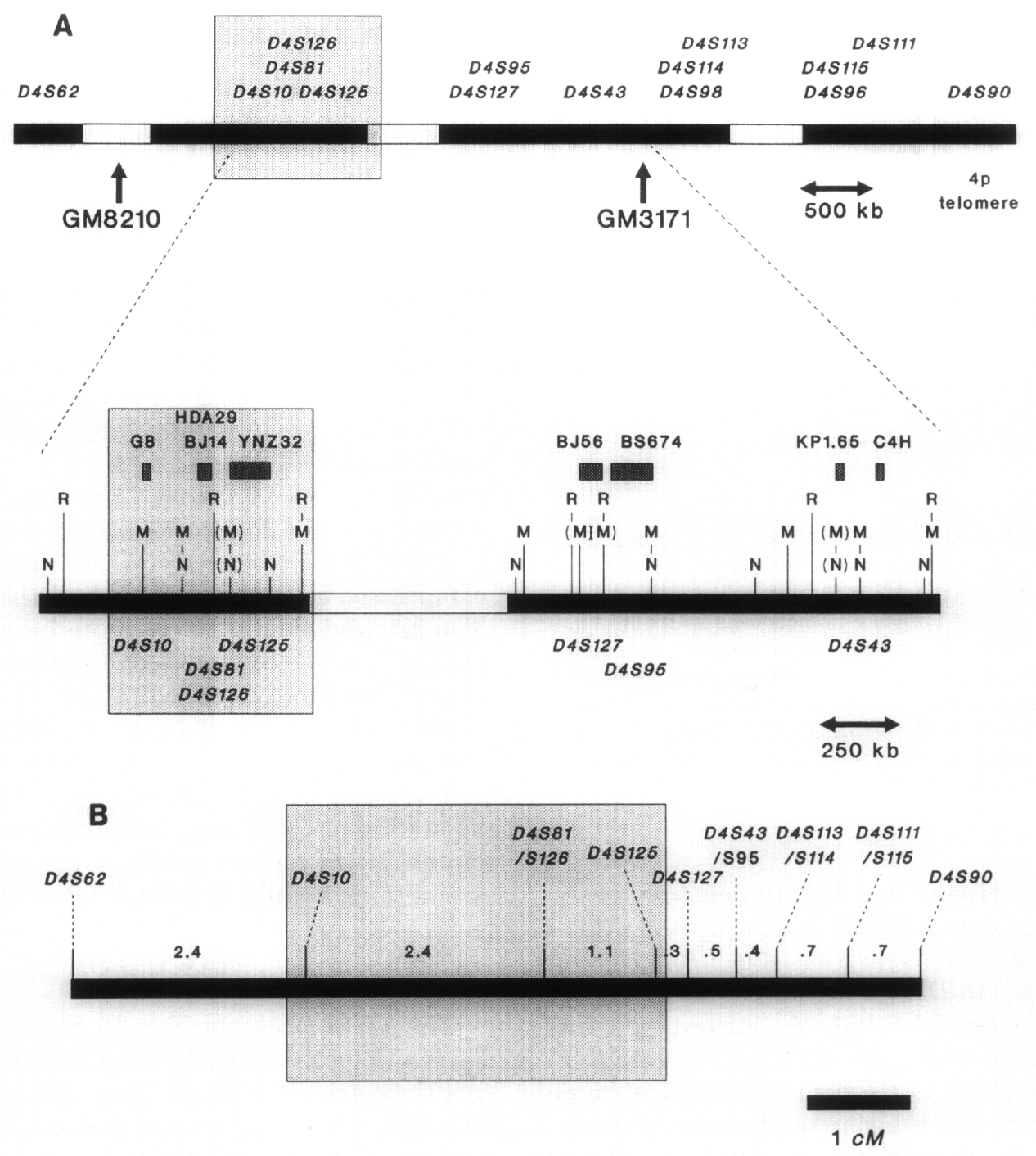

FIG. 3. Positions of $D 4 \$ 125, I 4 \$ 126$, and 145127 in the physical and genetic maps of 4 p 16.3 . (A) The long-range restriction map is based on Bucan et al. (3). The upper portion represents the map drawn to scale from D4S62 to the telomere and shows the placement of the chromosome breakpoints used in the somatic cell hybrid panel. The GM3171 deletion chromosome is in hybrids HHW842 and H60. The GM8210 $\mathrm{t}(4 ; 21)$ chromosome is in hybrids HHW847 and H67. Three gaps in the PFG map, representing areas that have yet to be visualized, are of unknown length and are therefore each denoted as an arbitrary light-color segment. In the lower portion, the central portion of the map is expanded to show the restriction sites ( $N=N o t I, M=M l u I, R=N r u I)$ detected in cell line GM1416B. Sites shown in parentheses are only partially digested in this cell line. The positions of the three markers on the visualized (darkened) segments were determined by single and double digests such as those examples shown in Fig. 4, using GM1416B and other DNA sources (3). The boxed area in each part of the figure denotes the region of increased recombination also illustrated on the genetic linkage map in $\mathbf{B}$. (B) The genetic linkage map shown represents a complete reanalysis of that reported in MacDonald et al. (20), with the addition of the three new markers (D4S125, D4S126, and D4S127) along with the proximal marker $D 4 \$ 62$ for comparison of recombination frequency. There was no significant difference in recombination frequency between male and female meioses. All marker loci that showed no recombination with each other are shown as appended symbols (e.g., D4S13/S95). The region of increased recombination is boxed as in A for comparison. The order of all marker loci was established without reference to physical map data and was supported by odds of at least 1000:1 with the single exception of $D 4 S 127$, which was placed with odds of about $200: 1$.

distal to this point, recombination is at least 10 -fold lower and is closer to that expected based on the average for the human genome. It is likely that at least a portion of the DNA that defines D4S1O must be included in the region of increased recombination, since several cases of intralocus crossing-over between individual RFLP sites have previously been reported (Gilliam et al., 1987a; Ikonen et al., 1990; Curtis et al.,
1989; Skraastad et al., 1989). $H D$ is located $3-4 \mathrm{cM}$ distal to D4S10 (Conneally et al., 1989). Consequently, the bulk of the crossovers reported between this marker and the genetic defect occur within the D4S10-D4S125 segment. Beyond this region, relatively fewer crossovers with $H D$ can be expected, and those events that have been observed have not permitted unequivocal positioning of the $H D$ gene, al- 


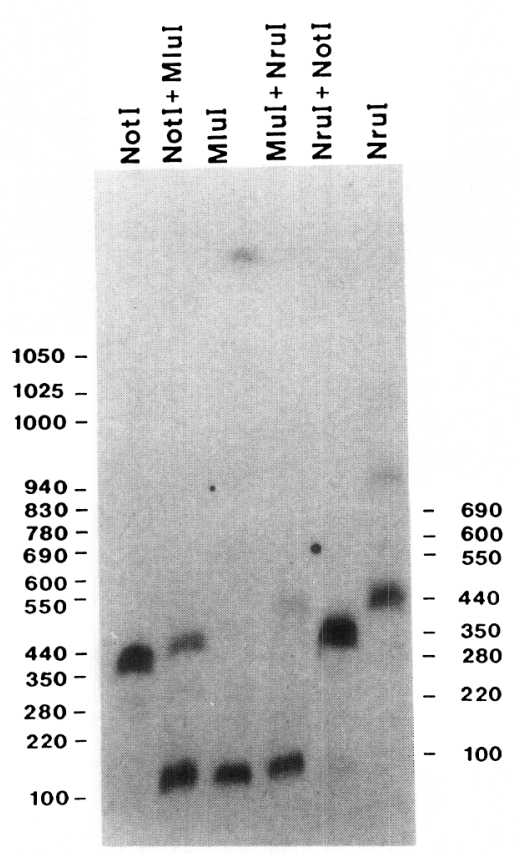

G8 (pKO82)

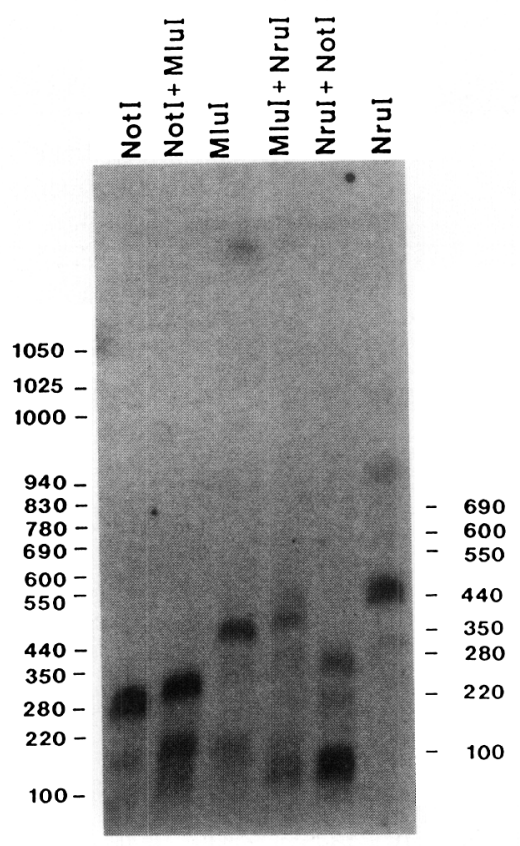

BJ14

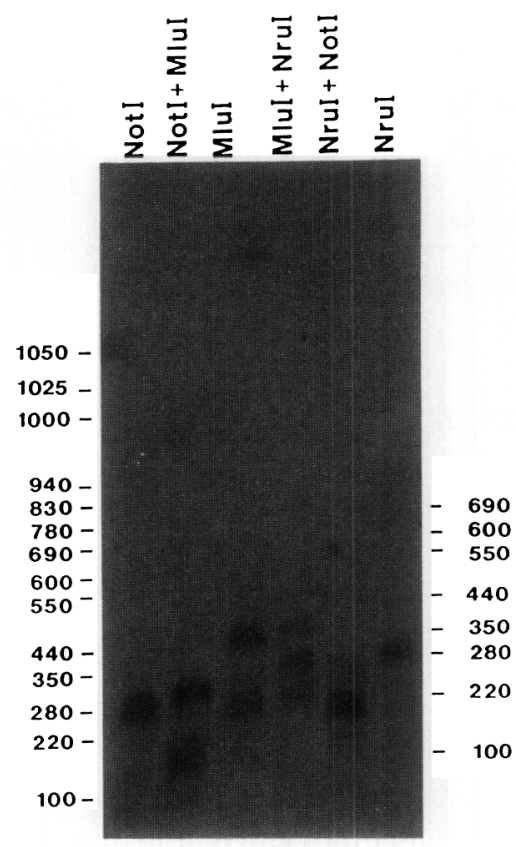

YNZ32

FIG. 4. Pulsed-field gel blots showing common fragments detected using single-copy probes at D4S10(pK082), D)4S126(pi309), and D4S125(pYNZ332). Pulsed-field gel electrophoresis using DNA from the human lymphoblastoid cell line GM1416B was carried out as described in Bucan et al. (3), and the same filter (published for pk082 in (31) was hybridized sequentially to each of the three prohes.

though a position very close to the telomere appears favored (MacDonald et al., 1989b; Bates et al., 1990).

Interestingly, the relative increase in recombination for the $200 \mathrm{~kb}$ between $D 4 S 10$ and D4S126 is ohserved equally in males and females. The increase might be due to the overall structure of the chromosome in the region, or could be the result of specific sequences that promote recombination. It has been reported that minisatellite sequences may mark frequent crossover sites, and it is conceivable that one or more of these will be found within this small segment.
However, several "variable number of tandem repeat" markers (VNTRs), including D4S125, D4S95, $D 4 S 115$, and $D 4 S 111$, have already been located within the more distal region where normal to reduced recombination rates are observed (Pohl et al., 1988; MacDonald et al., 1989a). Thus, not all tandemly repeated segments may act to promote recombination.

With a collection of recombination events already defined in the Venezuela reference pedigree, it should be possible to determine whether these crossovers oc-
A

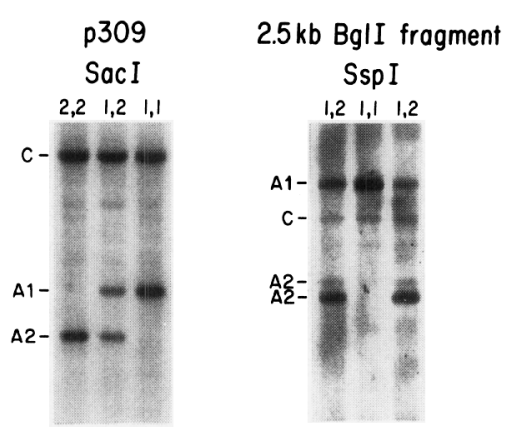

B

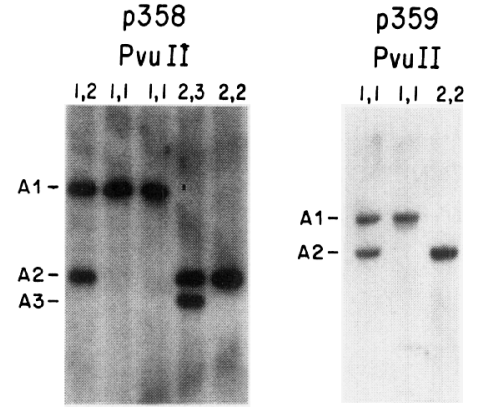

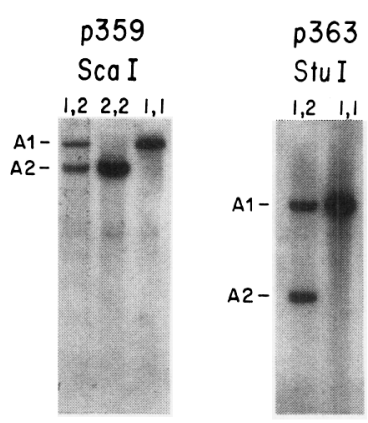

FIG. 5. RFLPs at the D4S126 and D4S127 loci. Allelic fragments (A1, A2, A3) are indicated for RFLPs detected with subclones or I) NA fragments from the cosmids BJ14 (A) and BJ56 (B). C denotes constant bands. Genomic DNAs isolated from lymphoblastoid cell lines were used in screening for RFLPs (9) with the following enzymes: ApaI, AvaI, BamHI, BanI. Banll, Bcll, BglI, BglII, BglIII, Bspl286, BstEII, BstNI, BstxI, DraI. EcoRI, EcoRV, HincII, HindIII, HinfI, HphI, KpnI, MspI, NciI, PstI, PuuII, RsaI, SacI, Sau96I, ScaI. StuI. StvI, TaqI, $X b a I$, and $X m n I$ 
TABLE 1

RFLPs at $D 4 S 126$ and $D 4 S 127$

\begin{tabular}{|c|c|c|c|c|c|c|}
\hline Locus & $\begin{array}{l}\text { Probe } \\
\text { name }\end{array}$ & $\begin{array}{l}\text { Restriction } \\
\text { enzyme }\end{array}$ & $\begin{array}{l}\text { Invariant } \\
\text { fragments } \\
\text { (kb) }\end{array}$ & $\begin{array}{c}\text { Allelic } \\
\text { fragments } \\
(\mathrm{kb})\end{array}$ & $\begin{array}{c}\text { Allele frequency } \\
\text { tested }\end{array}$ & Chromosomes \\
\hline \multirow[t]{4}{*}{$D_{4} S 126$} & p309 & SacI & 9.3 & 4.3 & 0.46 & 186 \\
\hline & & & & 3.8 & 0.54 & \\
\hline & 2.8-kb BglI & SspI & 8.4 & 12.5 & 0.85 & 52 \\
\hline & fragment & & & $5.6+6.2$ & 0.15 & \\
\hline \multirow[t]{9}{*}{$D 4 S 127$} & p358 & PvuII & & 3.1 & 0.61 & 232 \\
\hline & & & & 2.0 & 0.36 & \\
\hline & & & & 1.8 & 0.03 & \\
\hline & p359 & PuuII & & 6.0 & 0.61 & 126 \\
\hline & & & & 4.5 & 0.39 & \\
\hline & p359 & SacI & & 26 & 0.83 & 110 \\
\hline & & & & 20 & 0.17 & \\
\hline & p363 & StuI & & 10.1 & 0.40 & 186 \\
\hline & & & & 6.1 & 0.60 & \\
\hline
\end{tabular}

cur throughout the region or are clustered around particular sites. This will require cloning the region, saturating it with closely spaced DNA polymorphisms, and typing each of these in the critical crossover individuals. If the crossovers occur randomly throughout the D4S10-D4S125 stretch, then it will be necessary to determine whether the structure of the region differs in some significant way from that of the surrounding regions. Currently, the only atypical characteristic of the immediate $D 4 S 10$ segment is that over a stretch of at least $25-30 \mathrm{~kb}$ it is essentially devoid of repetitive DNA elements. This is certainly not the case for the original clones defining $D 4 . S 81$ and $D 4 S 126$, which do contain repetitive elements, indicating that the entire region of high recombination is not single-copy DNA. If it is found that the recombination events are clustered over a relatively small segment, it would then be possible to determine the specific sequence found at the site of high recombination frequency. Analysis of such sequences in the mouse has implicated a distinct molecular organization (Shiroishi et al., 1990). Interestingly, however, the same study presented evidence that sequences promoting recombination in the mouse histocompatibility complex are within the vicinity of, but not at, the "hot spot." Molecular definition of such a hot spot in humans would permit a direct experimental approach to identifying the fundamental mechanisms by which recombination is increased.

\section{ACKNOWLEDGMENTS}

We thank the members of the Venezuela Collaborative Huntington's Disease Project for collection of blood samples from the reference pedigree and Dr. Y. Nakamura and Dr. R. White of the Howard Hughes Medical Institute for the $\mathrm{pYNZ32}$ probe. We are grate- ful to Dr. A. M. Frischauf, Dr. David Housman, and Dr. Allan Tobin, our colleagues in the Hereditary Disease Foundation HD Collaborative Research Group, for their helpful discussions. 'This work was supported by NINCDS Grants NS16367 (Huntington's Disease Center Without Walls), NS22031, and NS20012 and by grants from the W. M. Keck Foundation, the Hereditary Disease Foundation, and the Huntington's Disease Society of America. B.A. and W.L.W received postdoctoral fellowships from the Huntington's Disease Society of America and the Wills Foundation.

\section{REFERENCES}

1. Anderson, M. A., AND Gusella, J. F. (1984). The use of cyclosporin A in establishing human EBV-transformed lymphoblastoid cell lines. In Vitro 20: 856-859.

2. Bates, G. P., MacDonald, M. E., Baxendale, S., SedlaCek, Z., Youngman, S., Romano, D., Whaley, W. L., ALlitTo, B. A., Poustka, A., Gusella, J. F., AND Lehrach, H. (1990). A YAC telomere clone spanning a favoured location of the Huntington's disease gene. Amer. J. Hum. Genet. 46: $762-775$.

3. Bucan, M., Zimmer, M., Whaley, L., I'oustka, A., Youngman, S., AllitTo, B., Ormondroyd, E., SMith, B., Pohl, T. L., MacDonald, M., Bates, G., Richards, J., Volinia, S., Gilliam, C., Sedlacek, Z., Collins, F., Wasmuth, J., Shaw, D., Gusella, J., Frischauf, A. M., and Lehrach, H. (1990). Physical maps of $4 \mathrm{p} 16.3$. The area expected to contain the Huntington disease mutation. Genomics 6: 1-16.

4. Conneally, P. M., Haines, J., Tanzi, R., WeXler, N., PenChaszadeh, G., Harper, P., Folstein, S., Cassiman, J., Myers, R., Young, A., Hayden, M., Falek, A., Tolosa, E., Crespi, S., Dimaio, L., Holmgren, G., Anvret, M., KanaZAWA, I., AND GUSELLA, J. (1989). No evidence of linkage heterogeneity between Huntington disease $(H D)$ and $\mathrm{G} 8$ (D4S10). Genomics 5: 304-308

5. Curtis, A., Millan, F., Holloway, S., Manie, M., Crosbie, A., Raeburn, J. A., AND Brock, D. J. (1989). Presymptomatic testing for Huntington's disease. A case complicated by recombination within the D4S10 locus. Hum. Genet. 81: 180 190.

6. Feinberg, A. P., And Vogelstein, B. (1983). A technique for 
radiolabelling DNA restriction endonuclease fragments to high specific activity. Anal. Biochem. 132: 6-13.

7. Gilliam, T. C., Tanzi, R. E., Haines, J. L., Bonner, T. I., Faryniarz, A. G., HobBs, W. J., MacDonald, M. E., Cheng, S. V., Folstein, S. E., Conneally, P. M., Wexler, N. S., AND Gusella, J. F. (1987a). Localization of the Huntington's disease gene to a small segment of chromosome 4 Hanked by $104 \mathrm{~S} 10$ and the telomere. Cell 50: 565-571.

8. Gilliam. T. C., Bucan, M., MacDonald, M. E., Zimmer, M., Haines, J. L., Cheng, S. V., Pollt, T. M., Witaley, W. L., Allitto, B. A., Faryniarz, A., Wasmuth, J. J., Frischauf, Conneally, P. M., Lehrach, H., and Gusella, J. F. (1987b). A DNA segment encoding two genes very tightly linked to Huntington's disease. Science 238: 950-952.

9. Gilliam, T. C., Healey, $\mathrm{S}$. T., MacDonald, M. E., Wasmuth, J., Stewart, G. D., Roy, J. C., and Gusella, J. F. $(1987 \mathrm{c})$. Isolation of polymorphic DNA from human chromosome 4. Nucl, Acids Res. 15: 1445-1458.

10. Gusella, J. F., Varsanyi-Breiner, A., Kao, F. T., Jones, C., Puck. T. T., Keys, C., Orkin, S., and Housman, D. (1979). Precise localization of the human $\beta$-globin gene complex on chromosome 11. Proc. Natl. Acad. Sci. ISSA 76:5239i.2. 43 .

11. Gusella, J. F., Keys, C., Varsanyi-Breiner, A., Kao, F. 'T., Jones, C., PUCK, T. T., AND Housman, D. (1980). Isolation and localization of DNA segments from specitic human chromosomes. Proc. Natl. Acad. Sci. USA 77: 2829-2833.

12. (Gusella, J. F., Wexler, N. S., Conneally, P. M., Naylor, S., Anderson, M. A., Tanzi, R. E., Watkins, P. C., Ottina, K.. Wallace, M., Sakaguchi, A., Young, A., Shoulson, I, BonILla, E.. AND MaRTIN, J. B. (1983). A polymorphic DNA marker genetically linked to Huntington's disease. Nature (London) 306: 234-238.

13. (iusella, J. F., Tanzi, R. E., Bader, P. I., Phelan, M. C., St'tevenson, R. Hayden, M. R., Hofman, K. .I, Faryniarz, A. G., AND GIBBons, K. (1985). Deletion of Huntington's disease linked ( 8 (D) $4 \$ 10)$ locus in Wolf-Hirschhorn syndrome. Nature (London) 318: 75-78.

14. Ikonen, E., Palo, J., OtT, J., Gusella, J., Somer, H., KaRIt.A, I.., Paintie, A., ani Pfictonfin, I. (1990). Huntington's disease in Finland: Jinkage disequilibrium of chromosome 4 RFLP haplotypes and exclusion of tight linkage between the disedse and D4S43 locus. Amer. J. Hum. Gertet. 46: $5 \cdot 11$

15. Landeghnt, J. E., JanSEN, in DE WaL, N., Fisser-Groen, Y. M., Bakker, E., Van der Ploeg, M., and Pearson, P. L. (1986). Fine mapping of the Huntington disease linked D 4 S10 locus by non-radioactive in situ hybridization. IIum. Genet. 73: 354-357.

16. I ander, E. S., Green, P.. Abrahamson, J., Barlow, A.. IALY, M. J., LinCOLN, S. E., AND NewBurg, L. (1987). Mapmaker: An interactive computer package for constructing primary linkage maps of experimental and natural populations. Genumic's 1: 174 -181.

17. Laurie, D. A., And Hulten, M. A. (1985). Further studies on chiasma distribution and interference in the human male. Ann. Hum. Genet. 49:203-214.

18. MacDonald, M. E., Anderson, M. A., Gilliam, T. C. Tranebjerg, L., Carpenter, N. J., Magenis, E., Hayden, M. R., Healey, S. T., Bonner, T. 1., and Gusella, J. F. (1987). A somatic cell hybrid panel for localizing DNA segments near the Huntington's disease gene. Genomics 1: 29 34.

19. MacDonald, M. E., Cheng, s. V., Zimmer, M., Haines,
J. L., Poustka, A. M., Allitto, B. A., Smith, B., Whaley, W. L., Romano, D., Jagadeesh, J., Lehrach, H., WasMUTH,J. J., F'RISCHAUf, A. M., AND GUSElla, J. F. (1989a). Clustering of multi-allele DNA markers near the Huntington's disease gene. J. Clin. Invest. 84: 1013-1016.

20. MacDonald, M. E., Haines, J. L., Zrmmer, M., Cheng, S. V., Youngman, S., Whaley, W. L., Bucan, W. L., ALlitTo, B. A., SMith, B., LeavitT, J., POUSTKa, A. M., Harper, P., Lehrach, H., Wasmuth, J. J., Frischauf, A. M., AND Gusella, J. F. (1989b). Recombination events suggest possible locations for the Huntington's disease gene. Neuron 3: 183-190.

21. Magenis, R. K., Gusella, J. F., Weliky, K., Olson, S., Haight, G., Toth-Fejel, S., and Sheehy, R. (1986). Huntington disease-linked restriction fragment length polymorphism localized within band p16.1 of chromosome 4 by in situ hybridization. Amer. J. Hum. Genet. 39: 383-391.

22. Maniatis, T., Fristsch, E. F., and SambrooK, J. (1982). "Molecular Cloning: A Laboratory Manual," Cold Spring Harbor Laboratory Press, Cold Spring Harbor, NY.

23. Martin, J. B., and Gusella, J. F. (1986). Huntington's disease: Pathogenesis and management. N. Engl. J. Med. 315: 1267-1276.

24. Nakamura, Y., Culver, M., O'Connell, P., Leppert, M., LATHROP, G. M., LALOUEL, J. M., AND White, R. (1988). Isolation and mapping of a polymorphic DNA sequence (pYNZ32) on chromosome 4p [D4S125]. Nucl. Acids Res. 16: 4186.

25. Pohl, T. M., Zimmer, M., MacDonald, M. E., SMITH, B., Bucan, M., Poutska, A., Volinia, S., Searle, S., Zehtner, G., Wasmuth, J. J., Gusella, J. F., Lehrach, H., and Frischauf, A. M. (1988). Construction of a Notl linking library and isolation of new markers close to the Huntington's disease gene. Nucl. Acids Res. 16: 9185-9198.

26. Poustka, A., Rackwitz, H., Frischalf, A., and Hohn, B (1984). Selective isolation of cosmid clones by homologous recombination in Escherichia coli. Proc. Natl. Acad. Sci. USA 81: 4129-41:33.

27. Richards, J. E., Gilliam, T. C., Cole, J. L., Drumm, M. L., Wasmuth, .J. .J., Gusei.t.A, I. F., and Collins, F. S. (1988). Chromosome jumping from $D 4 S 10(\mathrm{G} 8)$ towards the Huntington's disease gene. Proc. Natl. Acad. Sci. LSA 85: 64:376441 .

28. Robbins, C., Theilman, J., Youngman, S., Haines, J., Altherr, M. J., Harper, P.S., Payne, C., Junker, A., WasMUTH, J., AND HAYDEN, M. R. (1989). Evidence from family studies that the gene causing Huntington disease is telomeric to D4\$95 and D4\$90. Amer. J. Hum. Gerel. 44: 422-425.

29. Sealey, P. G., Whittaker, P. A., and Solthern, E. M. (1985). Removal of repeated sequences from hybridisation probes. Nucl. Acids Res. 13: 1905-1922.

30. Shiroishi, T., Hanzawa, H., Sagai, T., Ishiura, M., GojoboRI, 'I'., STEInmetz, M., ANd MoriwaKi, K. (1990). Recombinational hotspot specific to female meiosis in the mouse major histocompatibility complex. Immunogenetics 31: 79 88.

31. Skraastad, M. I., Bakker, E., Delange, L. F., VegterVan Der Vlis, M., Klein-Breteler, E. (. . VAN OMEN, G. J., AND PEarson, P. L. (1989). Mapping of recombinants near the Huntington's disease locus by using G8 (D4S10) and newly isolated markers in the D4\$10 region. Amer. J. Hum. Genet. 44: 560-566.

32. Smith, B., Skakecky, D., Bengi'ssun, U., Macienis, R. E., CARPENTER, N., AND WASMUTH, J. J. (1988). Isolation of 
DNA markers in the direction of the Huntington disease gene from the G8 locus. Amer. J. Hum. Genet. 42: 335-344.

33. Tanzi, R. E., Haines, J. L., Watkins, P. M., Stewart, D. G. Wallace, M. R., Hallewell, R., Wong, C., WeXler, N. S., Conneally, P. M., and Gusella, J. F. (1988). Genetic linkage map of human chromosome 21. Genomics 3: 129-136.

34. Wang, H. S., Greenberg, C. R., HewitT, J., Kalousek, D., AND HAYDEN, M. R. (1986). Subregional assignment of the linked marker G8 (D4S10) for Huntington's disease to chromosome 4p16.1-16.3. Amer. J. Hum. Genet. 39: 392-396.

35. Wasmuth, J. J., Carlock, L. R., SMith, B., and Immken, L. L. (1986). A cell hybrid and recombinant DNA library that facilitate identification of polymorphic loci in the vicinity of the Huntington disease gene. Amer. J. Hum. Genet. 39: $397-$ 403.

36. Wasmuth, J. J.. Hewitt, J., Smith, B., Allard, G., Haines, J. L., Skarecky, D., Partlow, E., ANd Hayden, M. R. (1988). A highly polymorphic locus very tightly linked to the Huntington's disease. Nature (London) 332: 734-736.

37. Whaley, W. L., Michiels, F., MacDonald, M. E., Romano,
D., Zimmer, M., Smith, B., LeavitT, J., Bucan, M., Haines, J., Gilliam, T. C., Zehetner, G., Frischauf, A. M., WasMUTH, J. J., LEHRACH, H., AND GuSELLA, J. F. (1988). Mapping of $D 4 S 98 / S 114 / S 113$ confines the Huntington's defect to a reduced physical region at the telomere of chromosome 4 . Nucl. Acids Res. 16: 11769-11780.

38. Youngman, S., Shaw, D. J., Gusella, J. F., MacDonald, M., Stanbridge, E. J., Wasmuth, J., AND HarPer, P. S. (1988). A DNA probe, D5 [D4S90], mapping to human chromosome 4p16.3. Nucl. Acids Res. 16: 1648.

39. Youngman, S., Sarafarazi, M., Bucan, M., MacDonald, M., Smith, B., Zimmer, M., Gilliam, C., Frischauf, A. M., Wasmuth, J. J., Gusella, J. F., Lehrach, H., HakPer, P. S., AND SHAW, D. J. (1989). A new DNA marker [D4S90] is terminally located on the short arm of chromosome 4 close to the Huntington's disease gene. Genomics 5: 802-809.

40. Zabel, B. U., NaYlor, S. L., Sakaguchi, A. Y., and GUSELLLA, J. F. (1986). Mapping of the DNA locus D4S10 and the linked Huntington's disease gene to 4p16-p15. Cytogenet. Cell Genet. 42: 187-190. 